\title{
Engineering Characteristics and Reinforcement Approaches of Organic Sandy Soil
}

\author{
Jun Hu $\mathbb{D}^{1},{ }^{1}$ Liang Jia $\mathbb{D},{ }^{2}$ Wei Wang $\mathbb{D},{ }^{3}$ Hong Wei, ${ }^{4}$ and Juan Du ${ }^{1}$ \\ ${ }^{1}$ Associate Professor, College of Civil Engineering and Architecture, Hainan University, Haikou, Hainan 570228, China \\ ${ }^{2}$ Associate Professor, College of Civil Engineering, Lanzhou University of Technology, Lanzhou, Gansu 730050, China \\ ${ }^{3}$ Professor, School of Civil Engineering, Shaoxing University, Shaoxing, Zhejiang 312000, China \\ ${ }^{4}$ Professor, College of Civil Engineering and Architecture, Hainan University, Haikou, Hainan 570228, China \\ Correspondence should be addressed to Wei Wang; wangwells@qq.com
}

Received 3 April 2018; Revised 11 August 2018; Accepted 10 September 2018; Published 24 October 2018

Academic Editor: Annan Zhou

Copyright ( 2018 Jun Hu et al. This is an open access article distributed under the Creative Commons Attribution License, which permits unrestricted use, distribution, and reproduction in any medium, provided the original work is properly cited.

\begin{abstract}
Organic sandy soil is widely distributed throughout Hainan Island. This study aimed at addressing the distribution, composition, and formation of organic sandy soil. The engineering properties of organic sandy soil were examined. The experimental results showed that the coefficient of uniformity and coefficient of curvature were 2.07 and 1.25, respectively. The maximum dry density and optimum water content were $1.723 \mathrm{~g} / \mathrm{cm}^{3}$ and $12.23 \%$, respectively. The undrained shear strength of organic sandy soil was around $37.5 \mathrm{kPa}$. The effective stress parameters $c$ and $\varphi$ were around $4 \mathrm{kPa}$ and $23^{\circ}$, respectively. The compound tangentexponential model was adopted for capturing the stress-strain behavior of organic sandy soil. As the unconfined compressive strength of the cement-admixed organic sandy soil was much lower than that of ordinary sand, some innovative ground improvement technologies were proposed for stabilizing organic sandy soil, such as thermal pile, fiber, and steel-, bamboo-, and freezing-cemented soil columns. The main purpose of these technologies is to enhance the bearing capacity of organic sandy soil but reduce the usage of cement, as the latter is not an eco-friendly material.
\end{abstract}

\section{Introduction}

Hainan is a rapidly growing tourism province in China with a very long coastline and plants of bays (Figure 1). Many construction projects are well under way in Hainan Island, especially in the coastal areas, so as to make it an international tourist island. Organic sandy soil is widely spread in this island, and field investigations have revealed that 8 of the 12 selected bays in Hainan Island have organic sandy soil (Haikou, Fengjia Bay, Yingge Bay, and Sanya). Organic soil is a material not suitable for engineering because of its high compressibility and low shear strength. It causes some engineering problems, such as inadequate strength after reinforcement or even failure of composite foundation because of its special engineering properties [1].

Although some studies have been conducted on organic soils [2-4], the knowledge of organic sand remains scanty. To deal with organic soils for construction projects such as ground improvement, one commonly adopted method is to stabilize it with some chemical admixtures [5]. Stabilization of soft ground by deep mixing [6] and jet grouting [7] is widely employed in coastal areas, such as Singapore and Hainan Island, for stability and deformation control in many ground improvement and underground construction projects such as tunneling or deep excavations. The use of cement to enhance the engineering properties of soft soils or sands has been widely used and well established [8, 9]. However, whether traditional treatment methods are available for organic sandy soil is still unclear. This study investigated the engineering properties (e.g., strength parameters) of organic sandy soil and proposed some innovative ground improvement techniques for this kind of sand. The tests in the current study are conducted according to the Chinese Standard for the soil test method (GB/T50123-1999); some other standards are also 


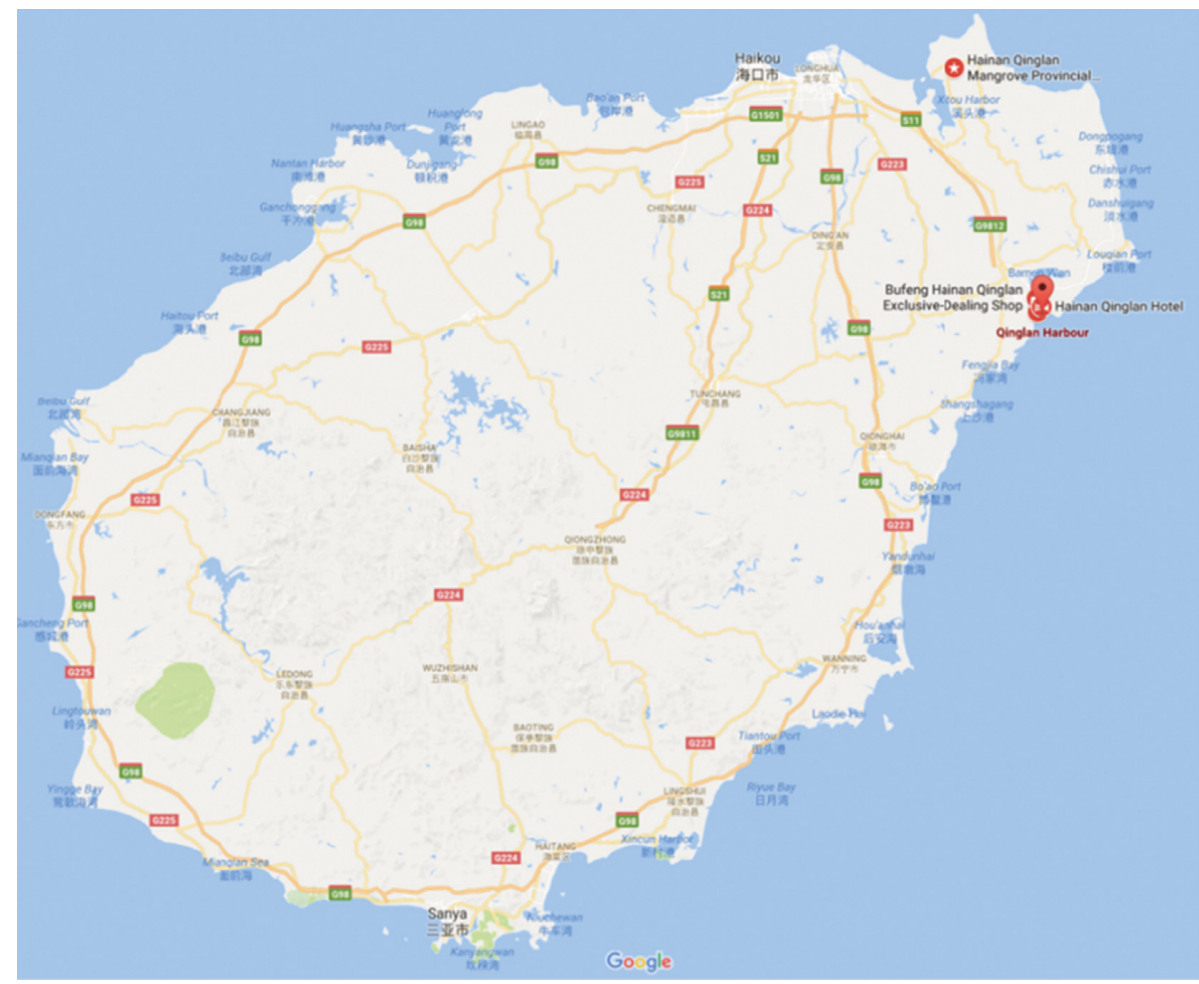

Figure 1: Map of key coastal bays in Hainan Province (Map data (c 2018 Google).

referenced, such as ASTM and British Standard, which will be specified where they are used.

\section{Formation of Organic Sandy Soil}

The location for in situ sampling of organic sandy soil in one construction site at Qinglan Harbor in Wenchang City is shown in Figure 1 (the red point). A quantitative analysis was conducted by the ASTM D2974 [10] to check the organic content in the sand. The results showed that the soil contained between $5 \%$ and $8 \%$ of organic matter content (Table 1).

Figures 2 and 3 show the scanning electron microscopic images of organic sandy soil and ordinary sand, respectively. The arrangement of particles reflects the microstructure of in situ organic sandy soils, as the tested samples are directly obtained from field. The smooth surface of the organic sandy soil is covered by a layer that makes the surface smooth with a few pores (Figure 2), completely contrary to the rough and porous surface of ordinary sand (Figure 3) [11]. It should be noted that the shape of microparticles is likely to have significant influence on the macromechanical behavior [12]; this effect was not investigated extensively in the current study.

A solubility analysis was also conducted to further check how the organic matters existed in the sands. The sand specimens were put in the oven at $70^{\circ}$ for $24 \mathrm{~h}$; the temperature was not to so high to burn the organic coat. Then, the sands were separated into three parts by crushing the samples, and the mass of each part was measured. The three parts were soaked in distilled water,
TABLE 1: Organic content of sand specimens from different sampling depths.

\begin{tabular}{lcc}
\hline Sample & Organic content (\%) & Sampling depth $(\mathrm{m})$ \\
\hline 1 & 7.56 & $2-3$ \\
2 & 6.88 & $3-4$ \\
3 & 5.26 & $4-5$ \\
\hline
\end{tabular}

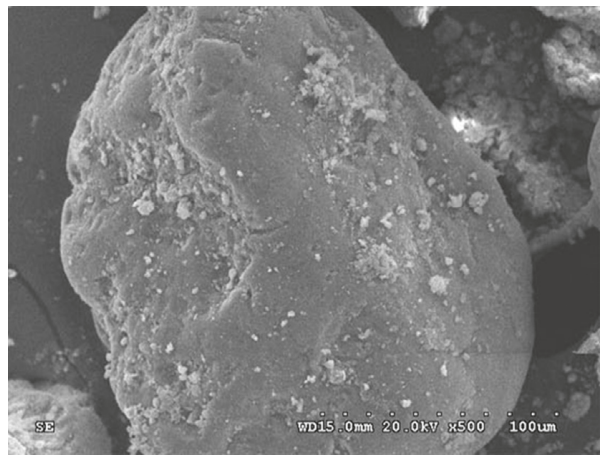

FIGURE 2: Scanning electron microscopic images of organic sandy soil.

$\mathrm{HCl}$ solution $(\mathrm{pH}=5)$, and $\mathrm{NaOH}$ solution $(\mathrm{pH}=9)$, respectively, for $48 \mathrm{~h}$. Each specimen was then taken out from the solution, dried, and weighed under room temperature to check the loss of mass. The percentage of mass loss for the specimens in distilled water, acid, and alkali solutions was $0.436 \%, 0.432 \%$, and $0.356 \%$, respectively. The small amount of mass loss indicated that the organic matters did not exist independently as particles, but were 


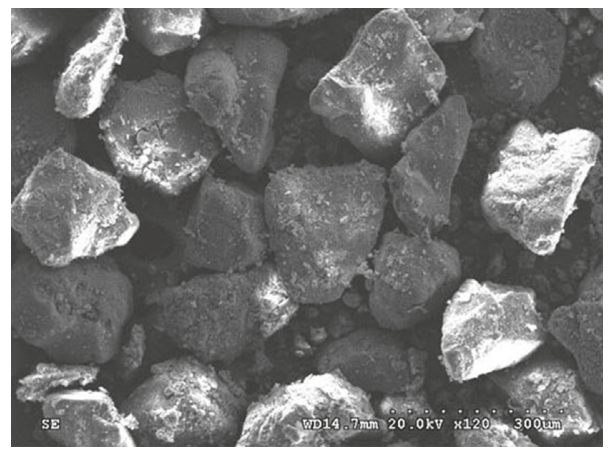

FIGURE 3: Scanning electron microscopic images of ordinary sand.

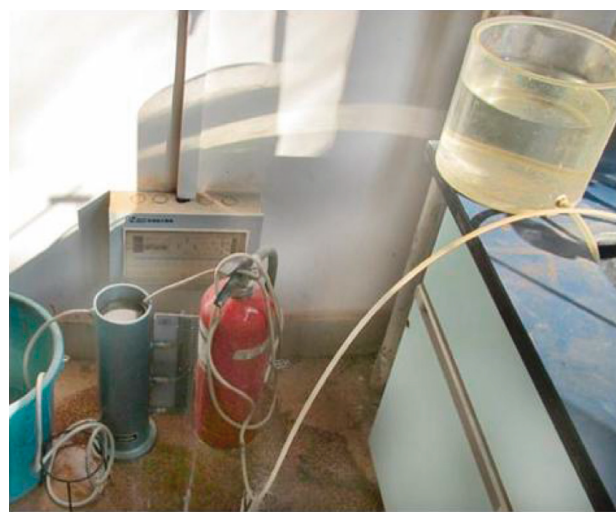

(a)

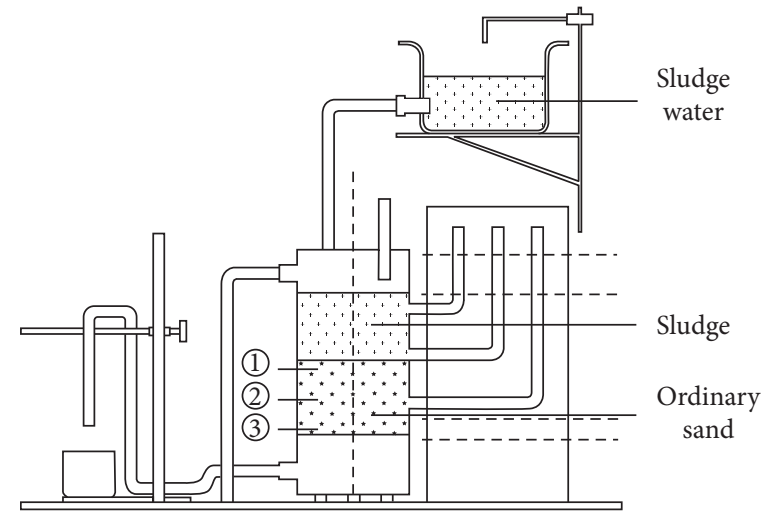

(b)

Figure 4: Experimental design for modeling the formation of organic sandy soil: (a) real product; (b) diagram.

combined with the sand particles closely. Organic matters may immerse in the pores or are adsorbed on the surface of the sand owing to the long-term microbial activity and physical or chemical effects. Due to the specific type of existence of organic matters, this sand is named "organic sandy soil."

The process for forming organic sandy soil was assumed to be as follows. The organic matters from dead animals or plants penetrated into the stratum due to the effect of rainwater and groundwater. Then, they were gradually adsorbed on the surfaces of sand particles across ages. Subsequently, they immersed into the pores of sand particles. Finally, the organic sandy soils were formed through the physical, chemical, and biological reactions between organic matter and minerals of sand particles. To model the formation process of organic sandy soil, an indoor experiment was conducted based on the concept of constant head permeability test (Figure 4). The sludge water and sludge were mixed with dead leaves to increase the organic content. After around 3 months, the organic content was determined in the ordinary sand. The organic content of parts 1,2 , and 3 was $0.31,0.03$, and 0 , respectively. Also, the organic content in the sand was found to decrease with the sampling depth, which was consistent with the results obtained from in situ specimens. This confirmed that the assumption about the formation of organic sandy soil was reasonable.

\section{Engineering Properties of Organic Sandy Soil}

According to BS 1377-2: 1990 [13], a dry sieving method was adopted to check the grain size distribution of organic sandy soil (Figure 5). It was identified that $d_{60}, d_{30}$, and $d_{10}$ were $0.18,0.14$, and $0.087 \mathrm{~mm}$, respectively.

The coefficient of uniformity $C_{\mathrm{u}}$ and the coefficient of curvature were 2.07 and 1.25 , respectively. The compaction tests shown in Figure 6 revealed that the maximum dry density and optimum water content of organic sandy soil were $1.723 \mathrm{~g} / \mathrm{cm}^{3}$ and $12.23 \%$, respectively. The minimum dry density of the sand was $1.570 \mathrm{~g} / \mathrm{cm}^{3}$, whereas its natural dry density was $1.617 \mathrm{~g} / \mathrm{cm}^{3}$. Therefore, the relative density of organic sandy soil in the natural state was around 0.56 . The specific gravity and permeability of the sand were found to be 2.621 and $3.257 \times 10^{-3} \mathrm{~cm} / \mathrm{s}$, respectively.

As the sand specimen was very easy to be disturbed, it was made in the laboratory. The sand was dried in air and sieved through a $2 \mathrm{~mm}$ sieve. The initial water content $w_{0}$ was measured, and the mass of water to be added $m_{\mathrm{w}}$ was calculated using the following expression:

$$
m_{\mathrm{w}}=\frac{m_{1}}{1+0.01 w_{0}} \times\left(w^{\prime}-w_{0}\right),
$$

where $m_{1}$ is the mass of sand and $w^{\prime}$ is the designed water content. Then, the mass of sand needed for one specimen $m_{2}$ was obtained using the following expression: 


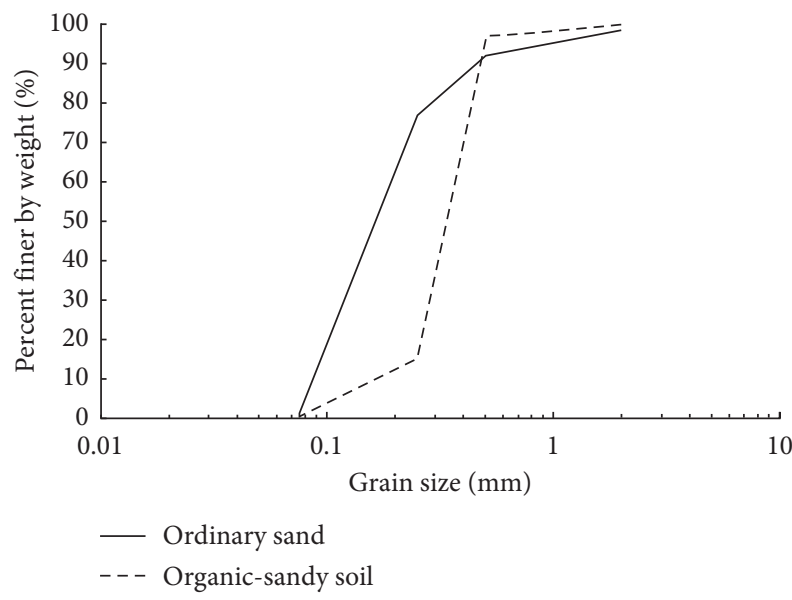

FIGURE 5: Grain size distribution curves of ordinary and organic sandy soils.

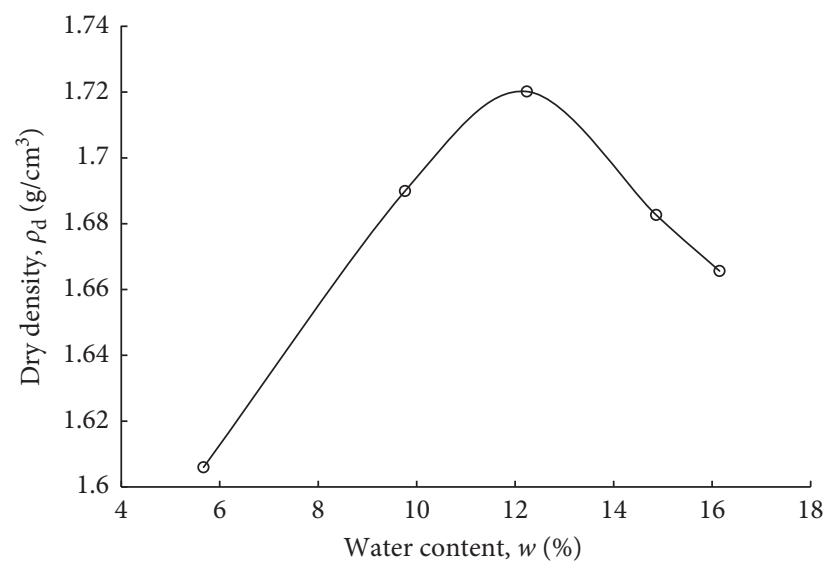

Figure 6: Dry density versus water content from compaction tests.

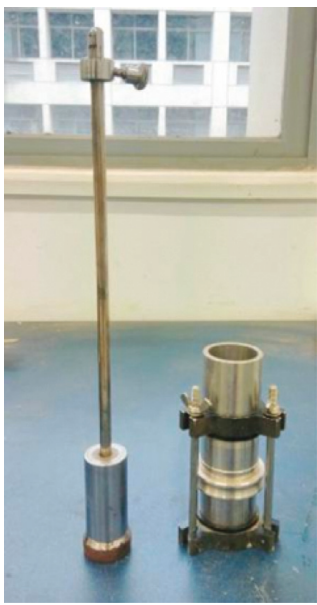

(a)

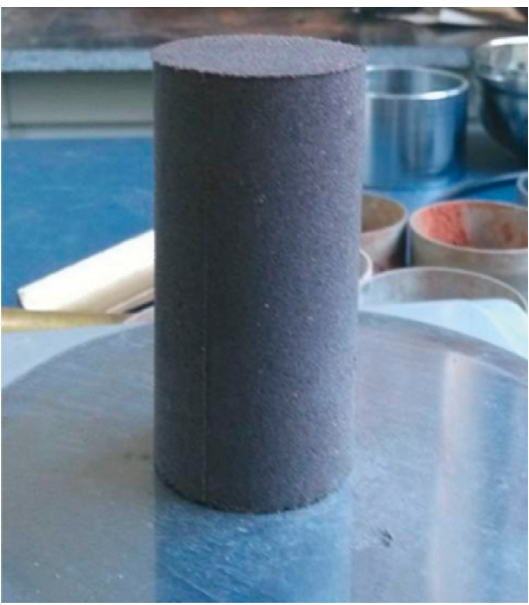

(b)

Figure 7: Compacted sand specimen: (a) compaction tool; (b) sand specimen.

$$
m_{2}=\left(1+0.01 w^{\prime}\right) \rho_{\mathrm{d}} V,
$$

where $\rho_{\mathrm{d}}$ corresponds to the dry density of sand while $V$ is the volume of specimen (with a diameter of $35 \mathrm{~mm}$ and length $70 \mathrm{~mm}$ ). The specimen of sand was compacted in a cylinder with grease inside, as shown in Figure 7. Five layers of sand were put into the cylinder, and 12 times of compaction were conducted for each layer to ensure the 
compaction quality. The average density and relative density of the samples are $1.71 \mathrm{~g} / \mathrm{cm}^{3}$ and 0.56 , respectively. These indices indicate that the samples are medium in terms of density.

Triaxial tests were conducted on the organic sandy soil with various confining pressures (i.e., 50, 150, and $200 \mathrm{kPa}$ ) using the Geocomp triaxial apparatus (Figure 8). The setup of the specimen and test process are illustrated in Figure 9.

Unconsolidated-undrained (UU) triaxial shear tests were used to determine the undrained shear strength of organic sandy soil (Figure 10). The stress-strain curves for various effective confining pressures are shown in Figure 10(a). The Mohr circle for the three confining pressures was similar (Figure 10(b)). Theoretically, the three circles should be exactly the same size, with horizontal envelope lines. The slight difference might be because it was difficult to saturate the specimen fully. Another reason for the difference may due to the variation in density of soil samples, as equal compaction energy was used for each soil layer. The undrained shear strength of the specimen was around $37.5 \mathrm{kPa}$. Figure 11 shows the results from the consolidated-undrained (CIU) triaxial shear test. When the shear strain was larger than $1 \%$, the effect of confining pressure was obvious and the specimen under higher confining pressure tended to achieve a greater shearing stress (Figure 11(a)). During the early stage of the test, positive excess pore pressure was generated (Figure 11(b)). Then, the negative excess pore pressure increased with shear strain, implying that the volume of the specimen was enlarged during shearing (i.e., stress dilatancy [14]; Figure 9(c)). The deviator stress of $15 \%$ shear strain was defined as failure stress (Figure 11(c)). With the generation of negative excess pore pressure, the effective stress Mohr circle was on the right side of the total stress Mohr circle. The total stress parameters $c_{\mathrm{u}}$ and $\varphi_{\mathrm{u}}$ were $14.6 \mathrm{kPa}$ and $21.85^{\circ}$, respectively. The effective stress parameters $c_{\mathrm{u}}^{\prime}$ and $\varphi_{\mathrm{u}}^{\prime}$ were $4.3 \mathrm{kPa}$ and $23.09^{\circ}$, respectively. Figure 12 exhibits the results from the consolidated-drained (CID) triaxial shear test. The deviator stress increased with the shearing strain, and the difference for various confining pressures within a strain of $0.05 \%$ was not much (Figure $12(\mathrm{a})$ ). When the strain increased continuously, higher confining pressure led to higher deviator stress. Further, a slight stress compression was observed during the early stage of shearing (Figure 12(b)). However, the volume strain increased with the increase in shearing strain in the later stage of shearing, up to a shearing strain of $10 \%$. It means that significant stress dilatancy was observed [15]. The Mohr circles in Figure 12(c) indicated that the effective stress parameters $c_{\mathrm{d}}$ and $\varphi_{\mathrm{d}}$ were $4.2 \mathrm{kPa}$ and $22.23^{\circ}$, respectively, consistent with those obtained from CIU tests.

The compound tangent-exponential model [16] was adopted to model the stress-strain curves obtained from the triaxial tests:

$$
q=\mathrm{A} \tan \left[\mathrm{B}\left(1-\mathrm{e}^{-\mathrm{C} \varepsilon}\right)\right],
$$

where $q$ is the deviator stress (in $\mathrm{kPa}$ ); $\varepsilon$ is the axial strain (in $\%$ ); and $\mathrm{A}, \mathrm{B}$, and $\mathrm{C}$ are the fitting parameters. The summary of fitting parameters for each stress-strain curve is given in Table 2. Figure 13 shows that the fitting curve agreed well

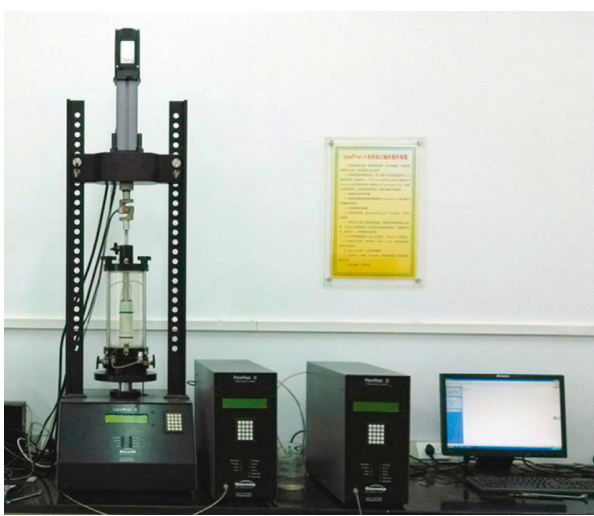

FIgURE 8: Geocomp triaxial apparatus.

with the experimental data from the triaxial test. Moreover, Figure 14 illustrates that the normalized stress-strain curves for UU and CIU tests fell into a narrow band for various applied confining pressures. The fitting formula was also obtained as follows:

$$
\begin{gathered}
U U: q=\tan \left[0.78\left(1-\mathrm{e}^{-3.6 \varepsilon}\right)\right], \\
C I U: q=\tan \left[0.78\left(1-\mathrm{e}^{-1.6 \varepsilon}\right)\right] .
\end{gathered}
$$

It showed that, for normalized stress-strain curves of UU and CIU tests, the fitting parameters $\mathrm{A}$ and $\mathrm{B}$ were set as 1 and 0.78 , respectively. The difference lay in the value of $\mathrm{C}$.

\section{Proposed Reinforcement Methods}

Figure 15 shows the results from unconfined compression tests for ordinary Portland cement-admixed sands. The three different types of sands were ordinary sand, organic sandy soil after removing its organic matters, and original organic sandy soil. The cement content was $10 \%$. However, the unconfined compressive strength was found to be significantly lower for the cement-treated organic sandy soil than for the cemented ordinary sand. To increase the engineering performance of the cement-treated organic sandy soil, the traditional way is to increase the cement content. Besides, several innovative techniques have been proposed for the ground improvement, which may be adopted for the organic sandy soil. The results in Figure 15 also indicate that, as a relatively weak and organic component, the organic coat may detach/crush under stress or be steadily degraded under acid or alkaline conditions.

Figures 16 and 17 show the outside view and schematic diagram of the thermal pile, respectively [17]. As shown in Figures 17(a) and 17(b), the thermal pile comprises a liquid pipe, a heating pipe, a brick pile, a drying section, and a liquid suction pipe. The heating pipe with a closed bottom is inserted into the soft ground. The brick pile surrounds the outer edge of the heating pipe, while a drying section is present around the brick pile. The liquid pipe lies within the center of the heating pipe, and its upper portion is higher than the top edge of the heating pipe. The top of the heating pipe is sealed. The liquid suction pipe and liquid pipe are connected with each other. The technology of thermal pile is 


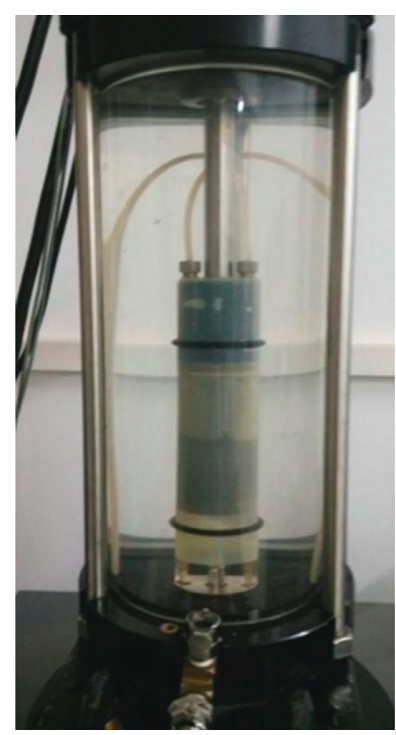

(a)

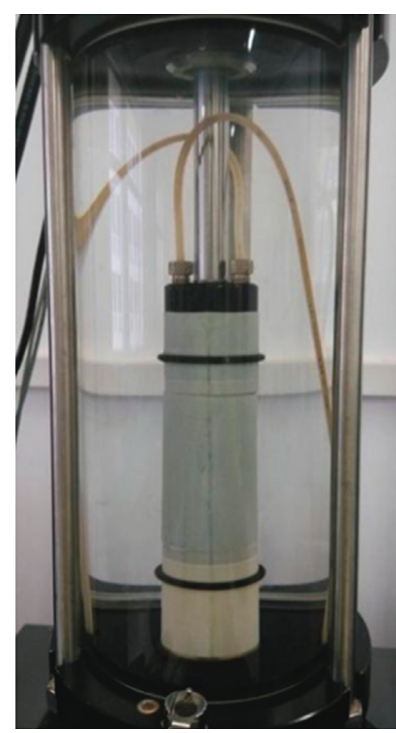

(b)

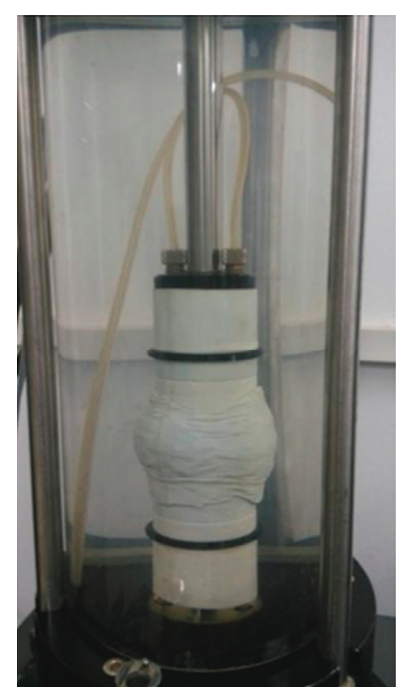

(c)

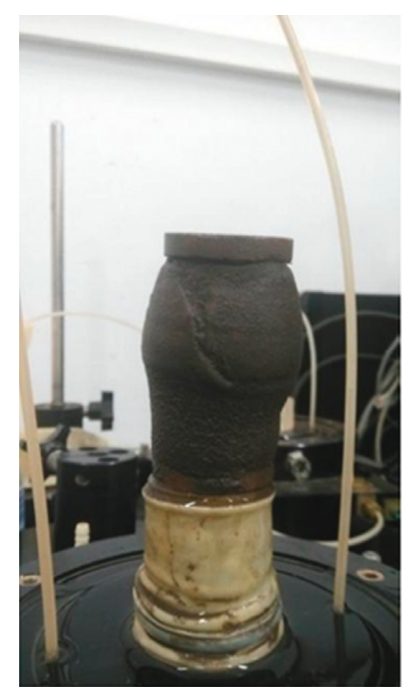

(d)

FIgUre 9: Procedure of the triaxial test: (a) setup of the specimen; (b) consolidation; (c) shearing; (d) dismantle of the specimen.

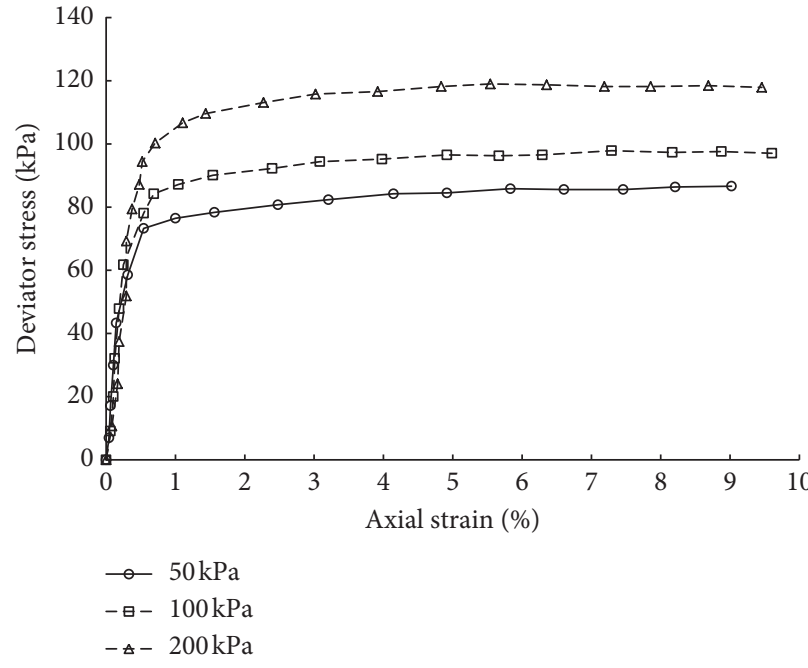

(a)

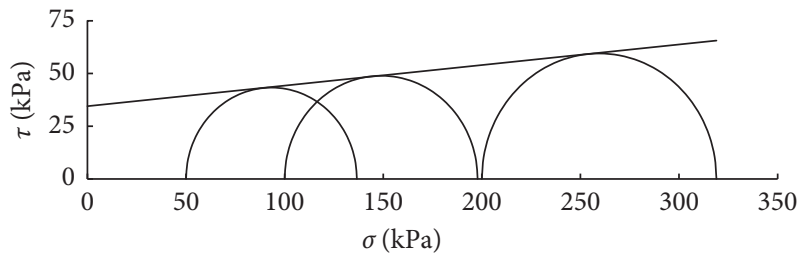

(b)

FIgURE 10: Results from the unconsolidated-undrained triaxial shear test: (a) stress-strain curves; (b) Mohr circle.

safe and environmental friendly, with easy-to-control quality. Moreover, it can be widely applied in engineering projects for a wide range of soils, such as bentonite and collapsible loess. For the treatment of organic sandy soil, the advantage of this technology is that it can remove the organic matters.

Figure 18 is the schematic diagram of the fiber- and steelreinforced cemented soil column, which includes the fiberreinforced cemented soil column and the steel cage [18]. The cylindrical steel cage is composed of longitudinal main bars and spiral stirrups outside of the cage. For accurate positioning, steel bars are used on the outside of the cylindrical framework. Strengthen tendons are fixed for each $2-2.5 \mathrm{~m}$ along the steel cage. This reinforcement method is easy to design, operate, and control quality. Moreover, the reinforcement depth can be very deep with reasonable cost. Therefore, the technique can be used in the ground improvement projects for the organic sandy soil foundation. It can also be used as a supporting structure during excavation.

Figure 19 shows the outside view of the bambooreinforced cemented soil column [19]. Bamboo is a fastest-growing natural resource available to mankind as a construction material; otherwise, it is burned or left to decay after its useful life [20]. One or more bamboos are inserted at the center of the column, and other bamboos are placed around them. The selected bamboos should be vertical in shape. The diameter of bamboo is usually between 50 and $100 \mathrm{~mm}$, which should be designed according to the 


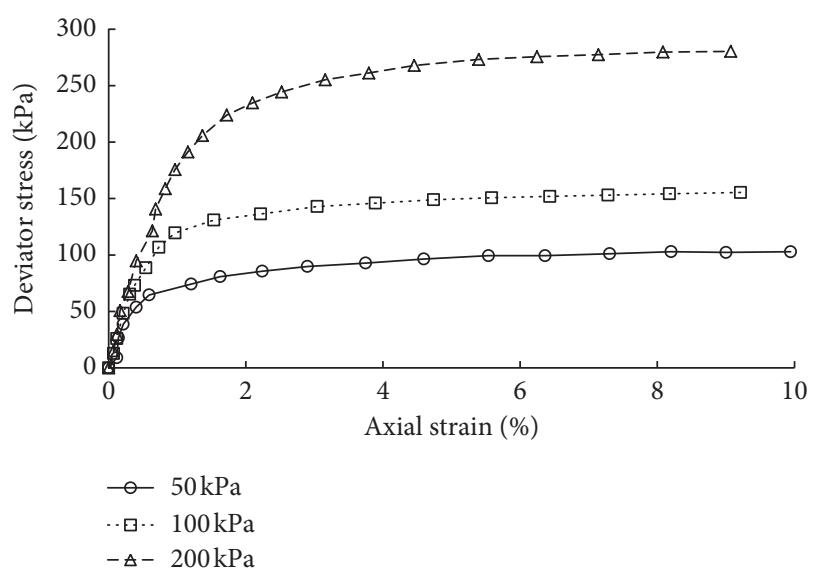

(a)

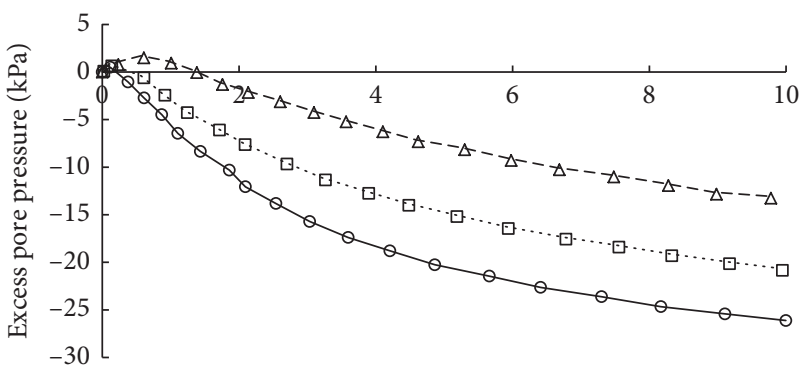

Axial strain (\%)

- $50 \mathrm{kPa}$

-. $-100 \mathrm{kPa}$

$-A-200 \mathrm{kPa}$

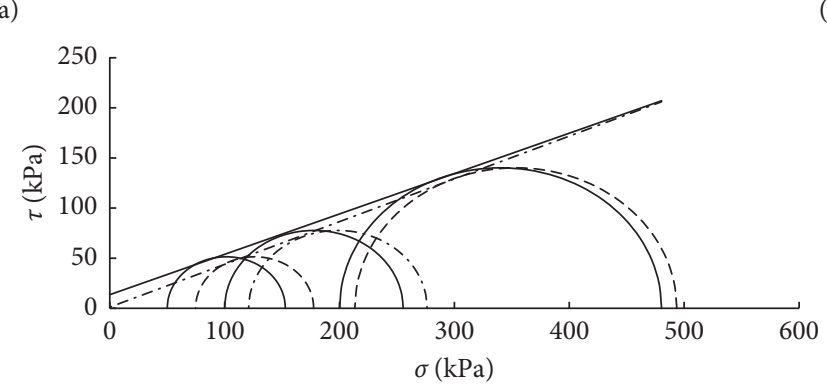

(b)

(c)

FIGURE 11: Results from consolidation-undrained triaxial shear test: (a) stress-strain curves; (b) variation in excess pore pressure with shearing strain; (c) Mohr circle.

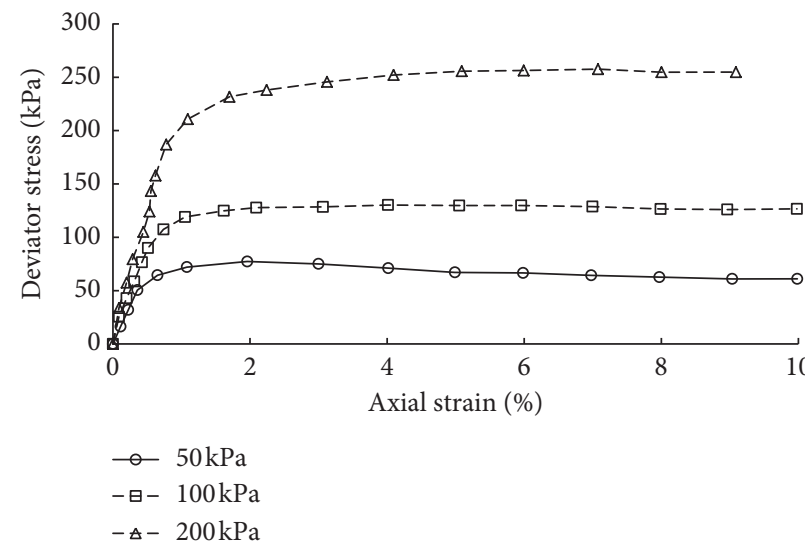

(a)

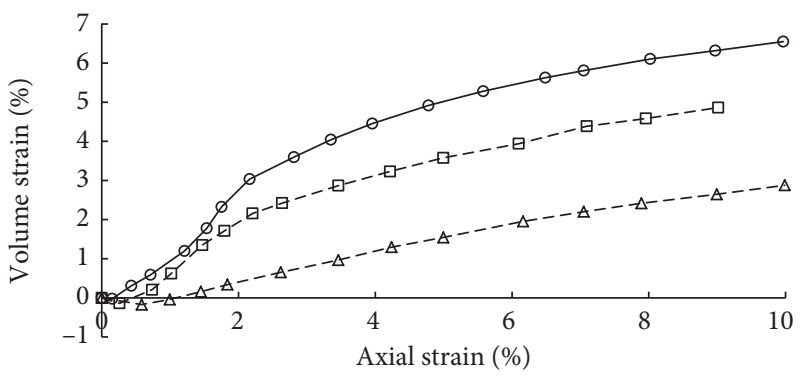

$-50 \mathrm{kPa}$

$-\bullet-100 \mathrm{kPa}$

$-\Delta-200 \mathrm{kPa}$

(b)

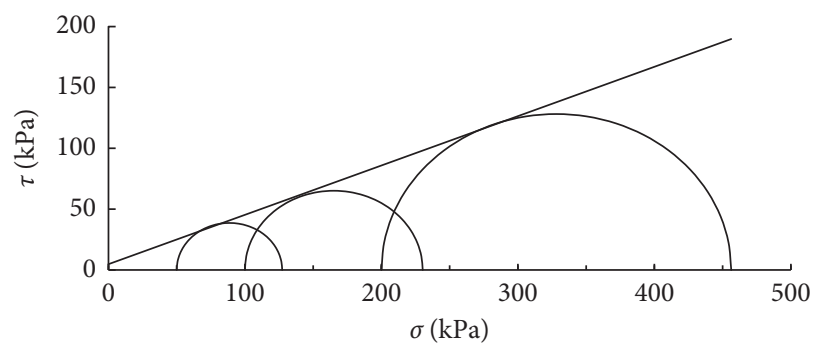

(c)

FIGURE 12: Results of the consolidation-drained triaxial shear test; (a) stress-strain curves; (b) variation in volume strain with shearing strain; (c) Mohr circle. 
TABLE 2: Fitting parameters for stress-strain curves.

\begin{tabular}{lcccc}
\hline Test & Confining pressure $(\mathrm{kPa})$ & A & B & C \\
\hline \multirow{3}{*}{ UU } & 50 & 3800 & 0.0225 & 0.03 \\
& 100 & 3200 & 0.038 & 2.6 \\
\hline \multirow{3}{*}{ CIU } & 200 & 3100 & 0.026 & 2.3 \\
& 50 & 3900 & 0.028 & 0.038 \\
\hline \multirow{2}{*}{ CID } & 100 & 5500 & 0.05 & 1.5 \\
& 200 & 7300 & 0.05 & 0.9 \\
\hline
\end{tabular}

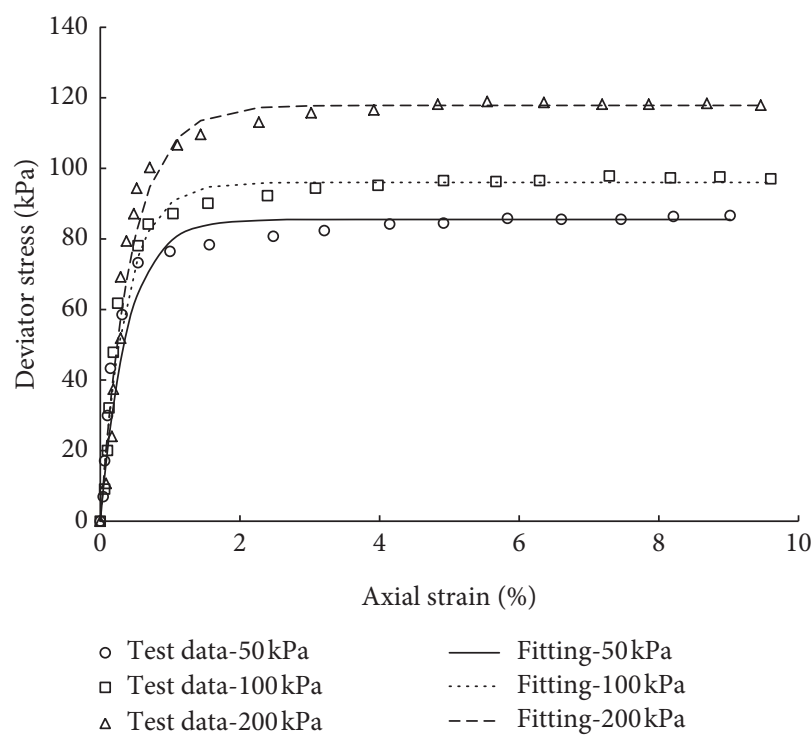

(a)

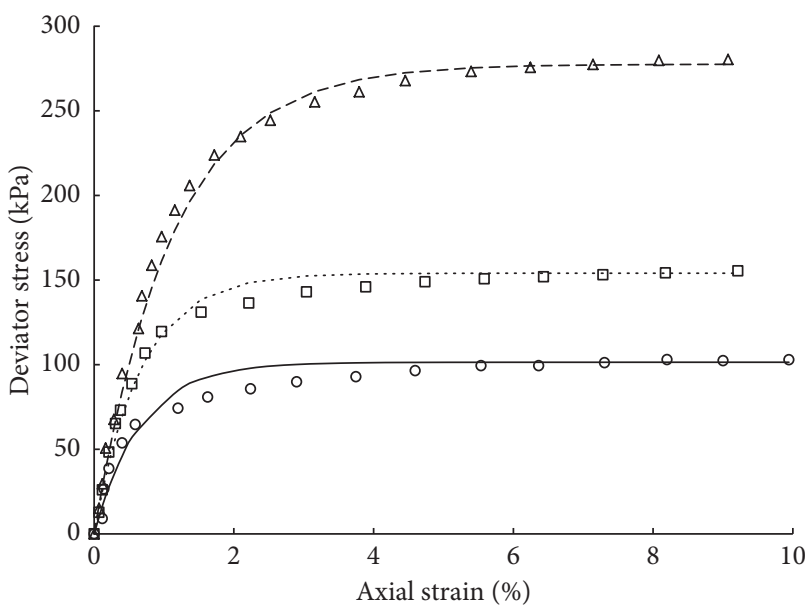

- Test data-50 kPa

- Test data- $100 \mathrm{kPa}$

$\triangle$ Test data- $200 \mathrm{kPa}$

— Fitting-50kPa

...... Fitting- $100 \mathrm{kPa}$

--- Fitting-200 $\mathrm{kPa}$

(b)

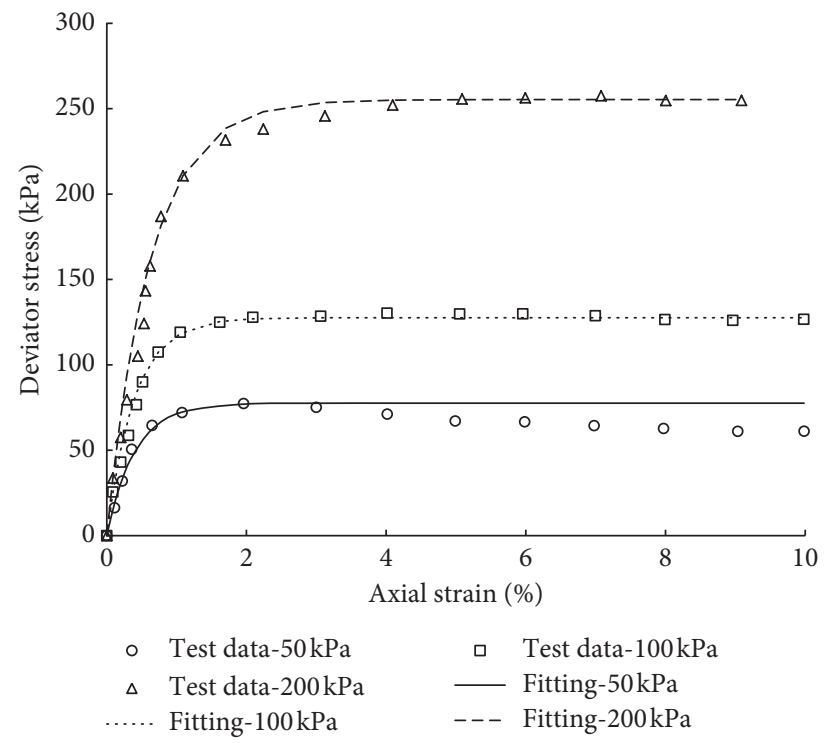

(c)

FIgURE 13: Fitting curves for data from the triaxial shear test: (a) unconsolidated-undrained triaxial shear test; (b) consolidation-undrained triaxial shear test; (c) consolidation-drained triaxial shear test. 


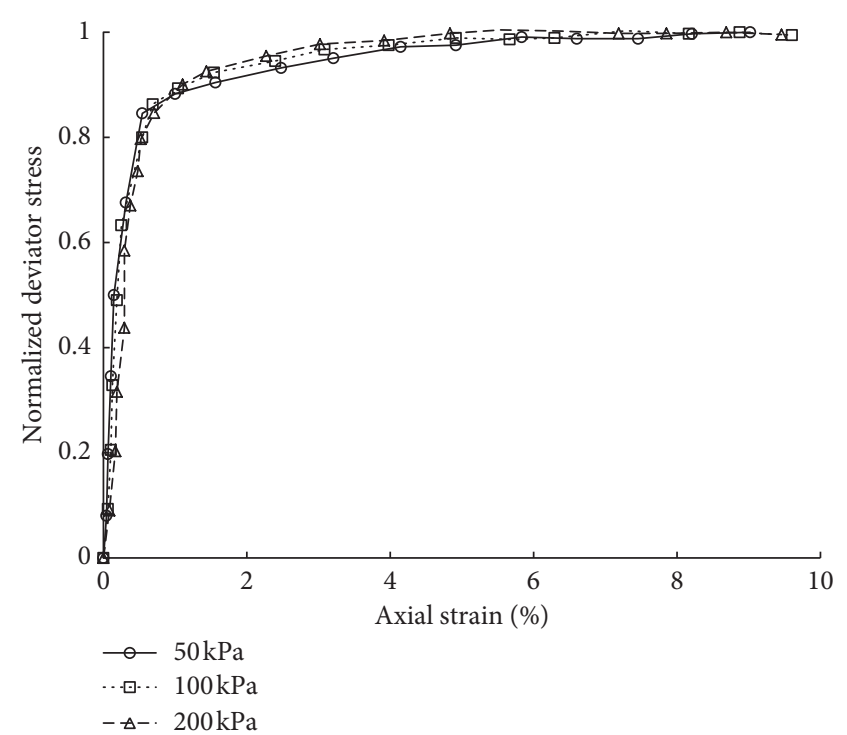

(a)

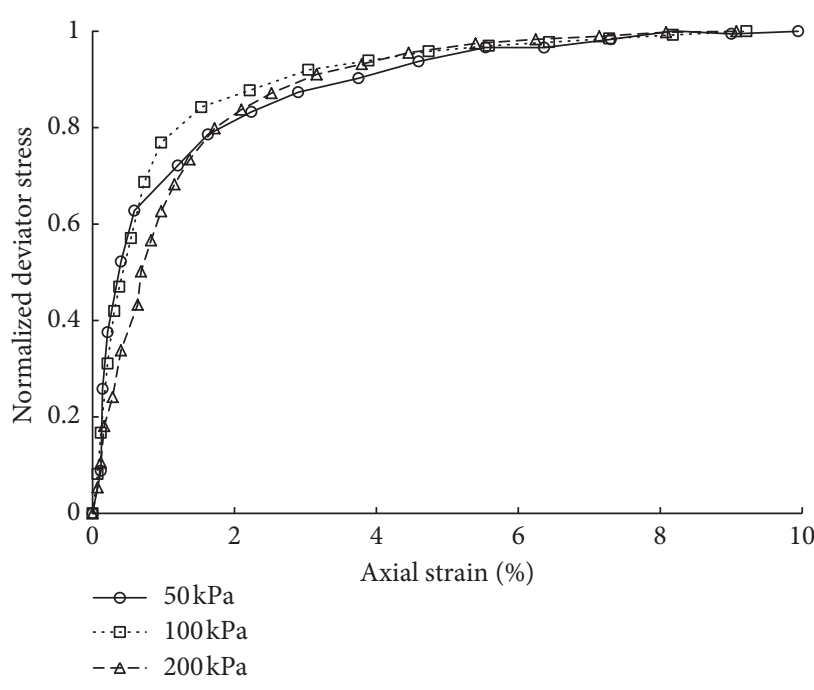

(b)

FIGURE 14: Normalized stress-strain curves: (a) unconsolidated-undrained triaxial shear test; (b) consolidation-undrained triaxial shear test.

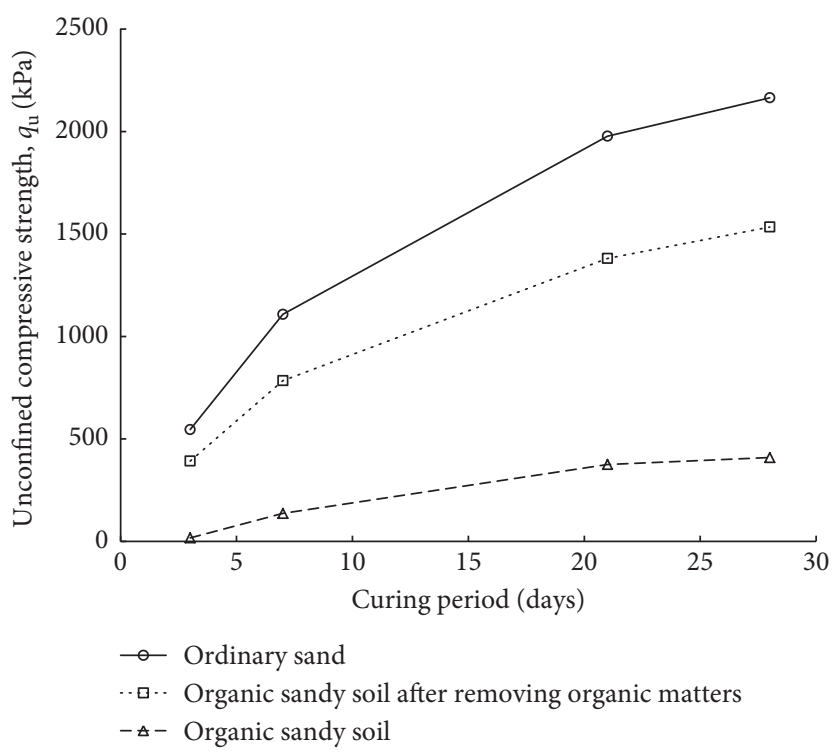

FIGURE 15: Unconfined compression test for cement-admixed sand.

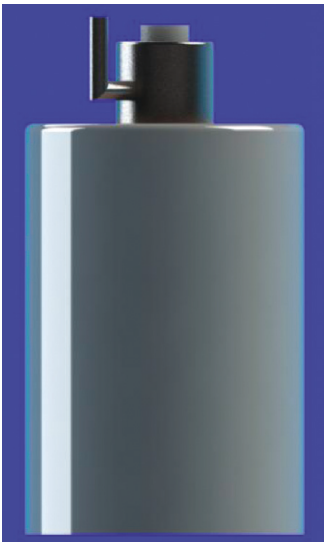

(a)

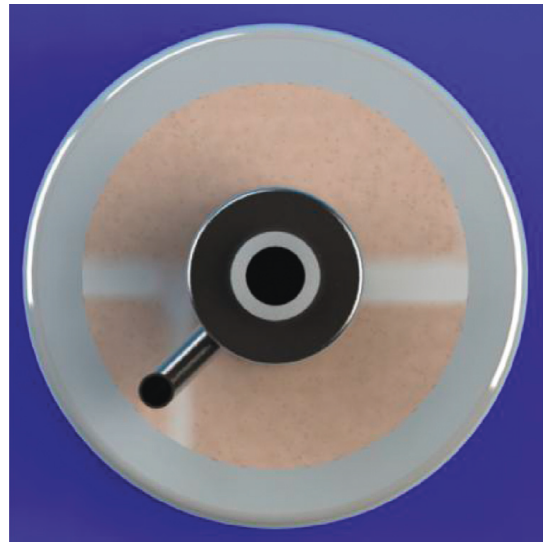

(b)

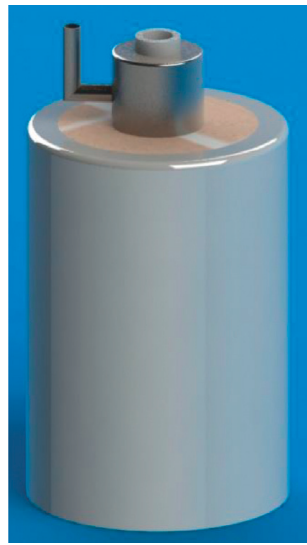

(c)

Figure 16: Outside view of the thermal pile: (a) front view; (b) plan view; (c) spatial pattern. 


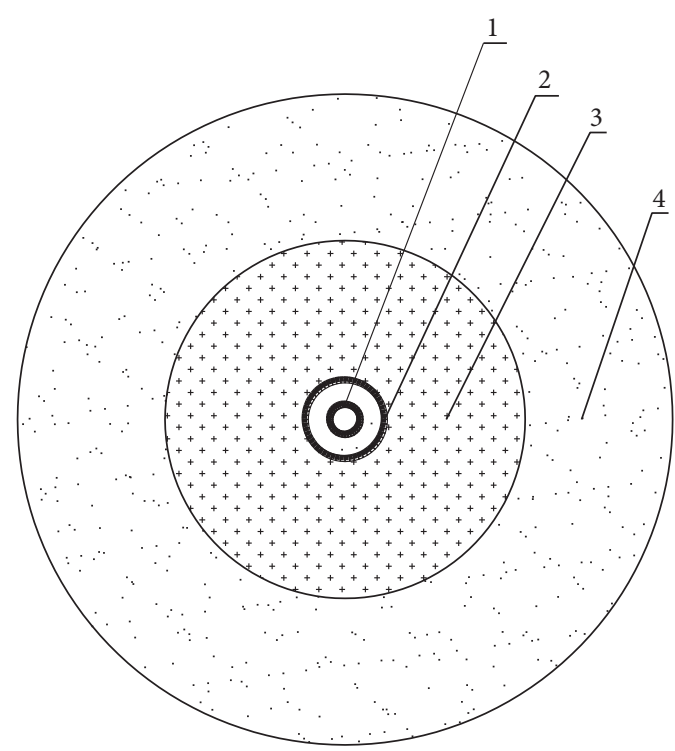

(a)

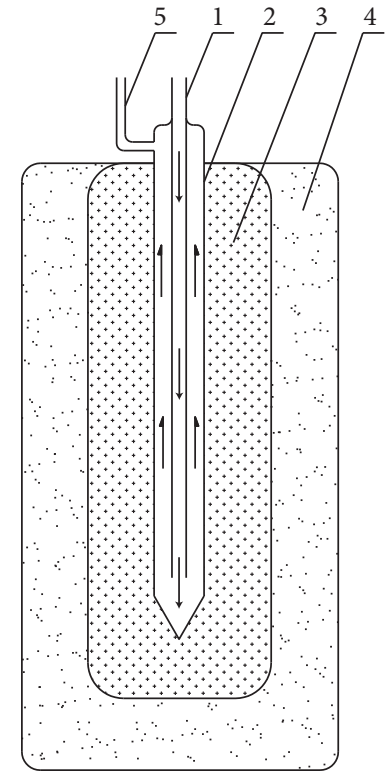

(b)

Figure 17: Schematic diagram of the thermal pile (1: liquid pipe; 2: heating pipe; 3: brick pile; 4: drying section; 5: liquid suction pipe); (a) plan view; (b) elevation view.

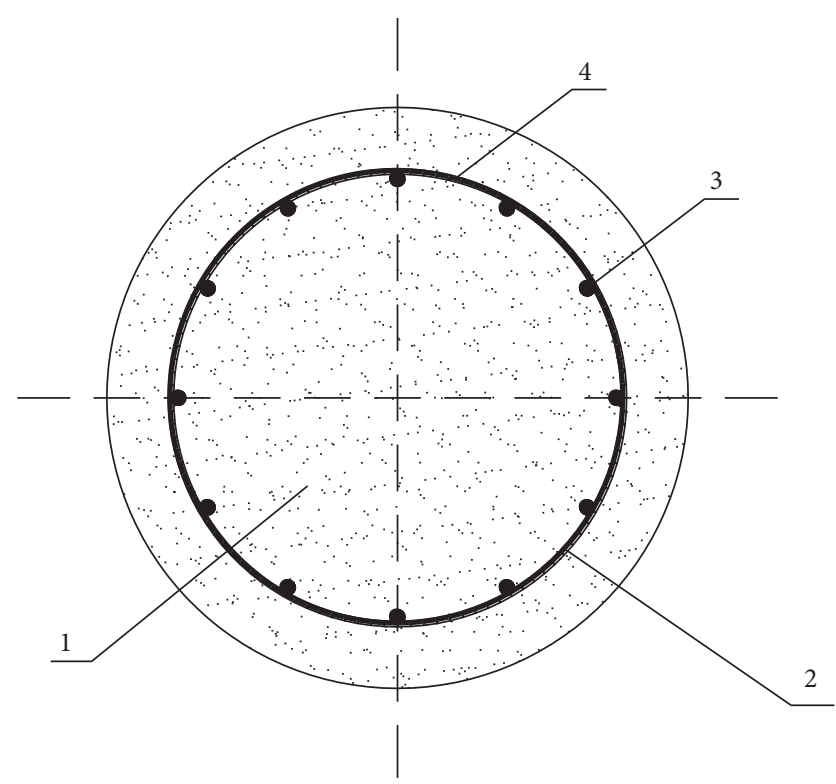

FIGURE 18: Schematic diagram of the fiber- and steel-reinforced cemented soil column (1: fiber-reinforced cemented soil column; 2: steel cage; 3: main bars; 4: spiral stirrups).

diameter of the cemented soil column. The bamboo should be inserted into the cement-admixed soil immediately after the mixing of the cement with soil to ensure that the process is finished before hardening of the cemented soil. The sharp end of the bamboo should be faced downward for easy penetration. First, the bamboo can be set up and penetrated into the slurry manually. Then, a pile driving machine can be used to insert fully the bamboo into the column. The bottom of the bamboo is around 1-2 m higher than the end of the column. The outer part of the bamboos is cut, and the
$20-30 \mathrm{~cm}$ length of the bamboo is left above the top of the column. Then, a steel net is used to connect all the columns through the top part of the bamboo, and concrete is cast on the top of the columns to act as a raft. The adding of bamboo increases the horizontal bearing capacity of the column. Due to the eco-friendly nature, low cost, and lower strength of bamboo compared with steel, this technology can be applied for the temporary ground reinforcement before conducting tunnel boring.

Figure 20 shows the outside view of the freezingcemented soil column, including the cement-mixed soil column and freezing pipe. The idea came from the artificial ground freezing method, which was adopted in this study to create a watertight connection between the tunnel and the shaft for conducting the tunnel boring $[21,22]$. The freezing pipe is made of seamless low-carbon steel or other pipes, such as PVC, PPR, ABS, and PE pipes. The typical diameter of the freezing pipe is $89,108,127,146$, or $159 \mathrm{~mm}$. The bottom of the freezing pipe is $0.5-1 \mathrm{~m}$ higher than the bottoms of the column. Using a freezing pipe in the cemented soil can protect the soil from ground motion caused by freezing and thawing cycles. Besides, it can reduce the cement content and increase the water-proof performance of the ground, which is of great importance for underground construction projects.

\section{Conclusions}

The organic sandy soils are widely distributed around the coastal areas of Hainan Island. The organic matters in this sand are immersed into the pores of sand particles and adsorbed on the surface of the sand. In this study, the formation process of the organic sandy soil was simulated by a laboratory test, and the tested organic content showed 


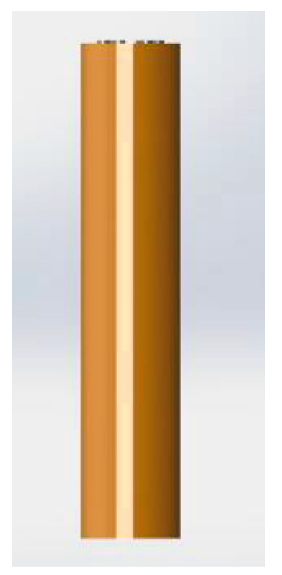

(a)

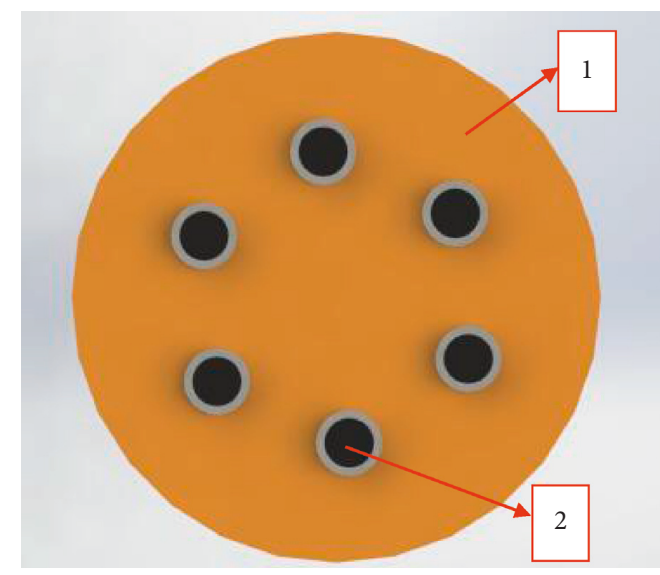

(b)

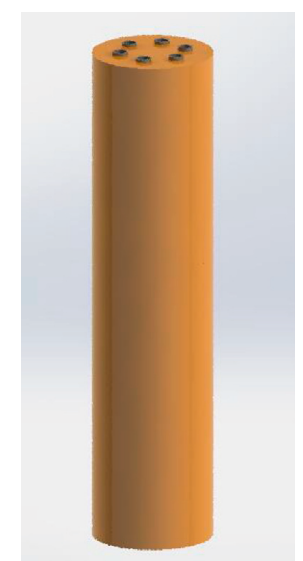

(c)

FiguRE 19: Outside view of the bamboo-reinforced cemented soil column (1: column body; 2: bamboo): (a) front view; (b) plan view; (c) spatial pattern.

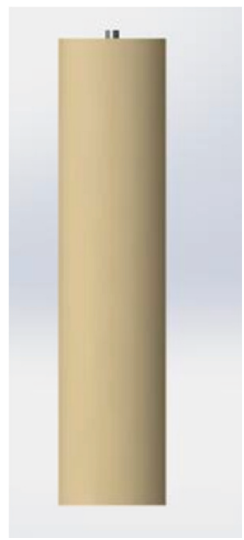

(a)

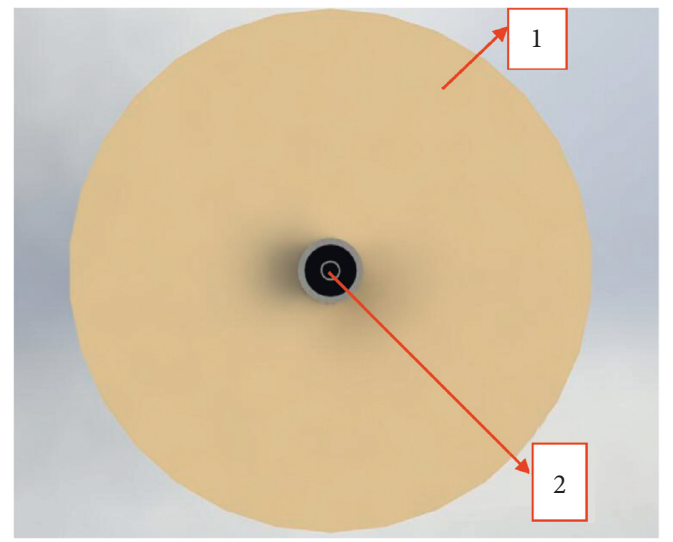

(b)

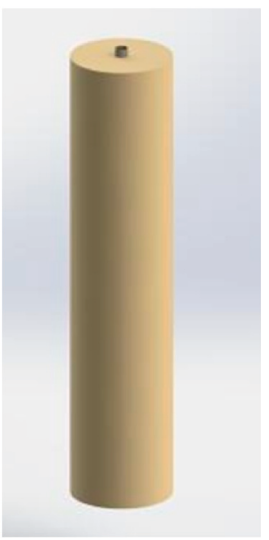

(c)

Figure 20: Schematic diagram of the freezing-cemented soil column (1: column body; 2: freezing pipe): (a) front view; (b) plan view; (c) spatial pattern.

a similar trend as that of the in situ specimen. The coefficient of uniformity $C_{\mathrm{u}}$ and the coefficient of curvature were 2.07 and 1.25 , respectively. The maximum dry density and optimum water content were $1.723 \mathrm{~g} / \mathrm{cm}^{3}$ and $12.23 \%$, respectively. The triaxial tests revealed that the undrained shear strength of organic sandy soil was around $37.5 \mathrm{kPa}$. The effective stress parameters $c$ and $\varphi$ were around $4 \mathrm{kPa}$ and $23^{\circ}$, respectively. The compound tangent-exponential model could capture the stress-strain behavior of organic sandy soil well. The unconfined compressive strength of the cemented organic sandy soil was much lower than that of ordinary sand. Therefore, several advanced techniques for stabilizing the organic sandy soil were introduced in detail, including thermal pile, fiber, and steel-, bamboo-, and freezing-cemented soil columns.

It should be noted that the cement-admixed organic sandy soil possesses a high variability in its engineering mechanical indices, such as the strength and stiffness $[23,24]$. To fully capture the variability, random fields may need to be employed [25]. As a limitation, this kind of variability was not considered in this study, which forms the scope of future investigations.

\section{Data Availability}

All the data used to support the findings of this study are included within the article.

\section{Conflicts of Interest}

The authors declare no conflicts of interest.

\section{Acknowledgments}

This study was supported by the Key Research \& Development Plan Sci-Tech Cooperation Program of Hainan Province in China (ZDYF2016226), the Scientific Research Project of Education Department of Hainan Province (Hnky2016ZD-7 and Hnky2015-10), the National Natural Science Foundation of China (51568044 and 41772311), and 
the Zhejiang Provincial Natural Science Foundation of China (LY17E080016). The assistance in laboratory tests offered by Mr. Y. S. Hu is greatly appreciated, who was a formerly graduate student at Hainan University.

\section{References}

[1] Q. Wand, H. Wei, J. Du, and H. Jun, "Design and research of mix ratio for infected gulf-phase organic sand based on orthogonal test," Natural Science Journal of Hainan University, vol. 33, no. 9, pp. 25-30, 2015, in Chinese.

[2] M. R. Mitchell, R. E. Link, K. Venkataramana, B. Rao, and D. Singh, "A critical review of the methodologies employed for determination of tensile strength of fine-grained soils," Journal of Testing and Evaluation, vol. 37, no. 2, article 101989, 2009.

[3] B. B. Huat, A. Asadi, and S. Kazemian, "Experimental investigation on geomechanical properties of tropical organic soils and peat," American Journal of Engineering and Applied Sciences, vol. 2, no. 1, pp. 184-188, 2009.

[4] A. Madaschi and A. Gajo, "One-dimensional response of peaty soils subjected to a wide range of oedometric conditions," Géotechnique, vol. 65, no. 4, pp. 274-286, 2015.

[5] M. Gunaratne, P. Stinnette, A. G. Mullins, C. L. Kuo, and W. F. Echelberger, "Compressibility relations for peat and organic soil," Journal of Testing and Evaluation, vol. 26, no. 1, pp. 1-9, 1998.

[6] Y. Liu, F. H. Lee, S. T. Quek, E. J. Chen, and J. T. Yi, "Effect of spatial variation of strength and modulus on the lateral compression response of cement-admixed clay slab," Géotechnique, vol. 65, no. 10, pp. 851-865, 2015.

[7] P. Croce, A. Flora, and G. Modoni, Jet Grouting, CRC Press, Taylor \& Francis Group, Boca Raton, FL, USA, 2014.

[8] S. Sugawara, S. Shigenawa, H. Gotoh, and T. Hosoi, "Large scale jet grouting for prestrutting in soft clay," in Proceedings of 2nd International Conference on Ground Improvement Geosystems, pp. 353-356, Tokyo, Japan, May 1996.

[9] K. Yao, Q. Chen, J. Ho, H. Xiao, and F. H. Lee, "Straindependent shear stiffness of cement-treated marine clay," Journal of Materials in Civil Engineering, vol. 30, no. 10, article 04018255, 2018.

[10] ASTM Standard, "Standard test methods for moisture, ash, and organic matter of peat and other organic soils," Annual Book of ASTM Standards, West Conshohocken, PA, USA, 1993.

[11] J. Yi and H. Wei, "Existing form and causes of bay facesorganic sand," Applied Mechanics and Materials, vol. 405408, pp. 2730-2733, 2013.

[12] A. Afzali-Nejad, A. Lashkari, and P. T. Shourijeh, "Influence of particle shape on the shear strength and dilation of sandwoven geotextile interfaces," Geotextiles and Geomembranes, vol. 45, no. 1, pp. 54-66, 2017.

[13] British Standard, Methods of Test for Soils for Civil Engineering Purposes, British Standard, London, UK, 1990.

[14] W. P. Rowe, "The stress-dilatancy relation for static equilibrium of an assembly of particles in contact," in Proceedings of the Royal Society A: Mathematical, Physical and Engineering Sciences, vol. A269, pp. 500-527, London, UK, October 1962.

[15] K. Been and M. G. Jefferies, "A state parameter for sands," Géotechnique, vol. 35, no. 2, pp. 99-112, 1985.

[16] W. Wang, P. Jin, and F. Zhang, "Direct shear test of short-fillage municipal solid wastes and its shear stress-deformation model," Rock and Soil Mechanics, vol. 32, no. 1, pp. 166-170, 2011, in Chinese.
[17] J. Hu, "Reinforcement pile with heat," China Patent ZL201620031077.X, 2016, in Chinese.

[18] J. Hu, "Reinforcement fiber cement soil pile," China Patent ZL201521085879, 2015, in Chinese.

[19] J. Hu and L. Jia, "Bamboo reinforced cement mixing pile," China Patent ZL201420614713, vol. 2, pp. 10-23, 2014, in Chinese.

[20] R. Sudin and N. Swamy, "Bamboo and wood fibre cement composites for sustainable infrastructure regeneration," Journal of Materials Science, vol. 41, no. 21, pp. 6917-6924, 2006.

[21] B. Stille, J. Brantmark, L. Wilson, and U. Hakansson, "Ground freezing design in tunnelling-two case studies from Stockholm," in Proceedings of Tunnels and Underground Structures, J. Zhao, J. N. Shirlaw, and R. Krishnan, Eds., pp. 185-190, Balkema, Rotterdam, Netherlands, 2000.

[22] G. Russo, A. Corbo, F. Cavuoto, and S. Autuori, "Artificial ground freezing to excavate a tunnel in sandy soil. Measurements and back analysis," Tunnelling and Underground Space Technology, vol. 50, pp. 226-238, 2015.

[23] Y. Pan, H. Xiao, F. H. Lee, and K. K. Phoon, "Modified isotropic compression relationship for cement-admixed marine clay at low confining stress," Geotechnical Testing Journal, vol. 39, no. 4, article 20150147, 2016.

[24] Y. Liu, Y. Jiang, H. Xiao, and F. H. Lee, "Determination of representative strength of deep cement-mixed clay from core strength data," Géotechnique, vol. 67, no. 4, pp. 350-364, 2017.

[25] Y. Liu, L. Q. He, Y. J. Jiang, M. M. Sun, E. J. Chen, and F. H. Lee, "Effect of in-situ water content variation on the spatial variation of strength of deep cement-mixed clay," Géotechnique, vol. 68, pp. 1-15, 2018. 


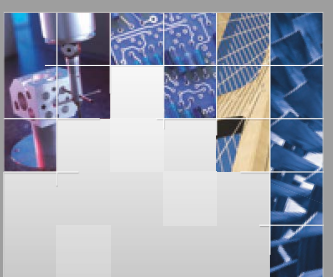

\section{Enfincering}
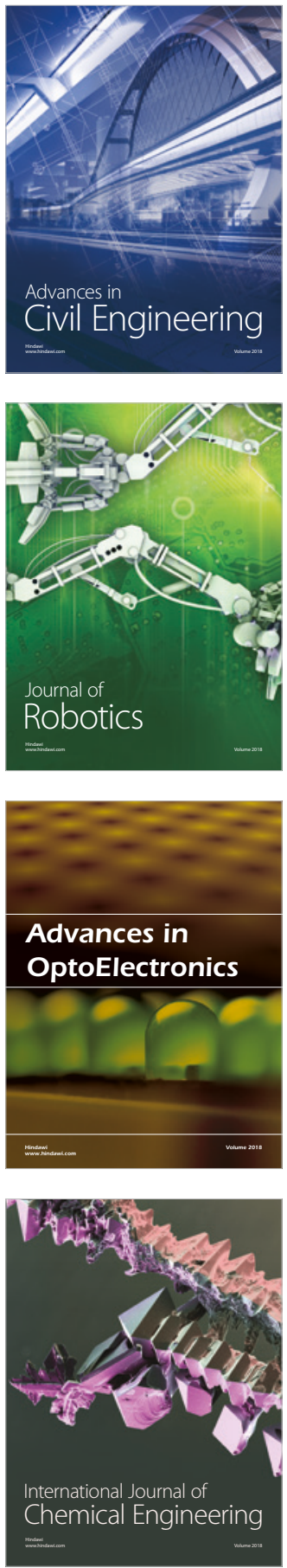

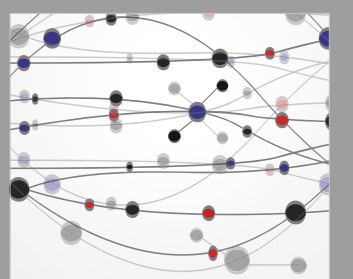

\section{Rotating \\ Machinery}

The Scientific World Journal

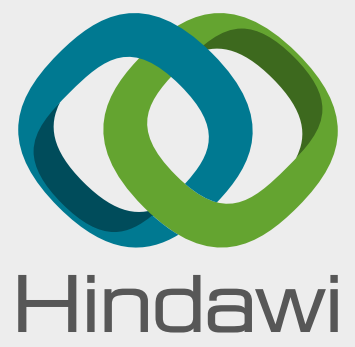

Submit your manuscripts at

www.hindawi.com
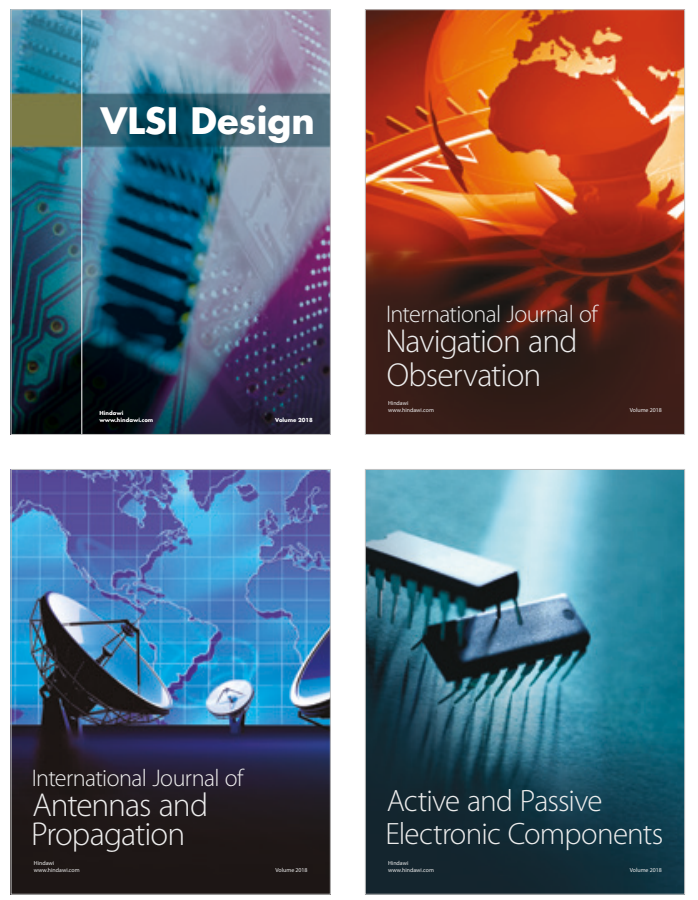
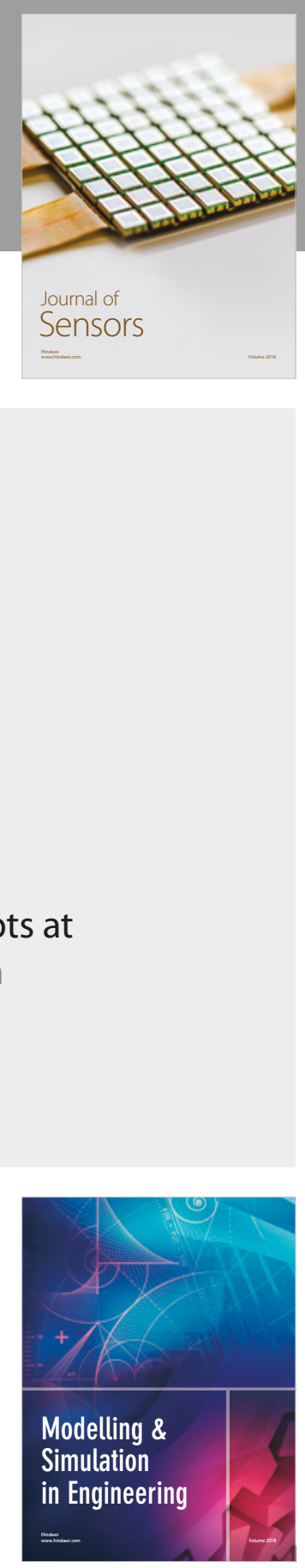

\section{Advances \\ Multimedia}
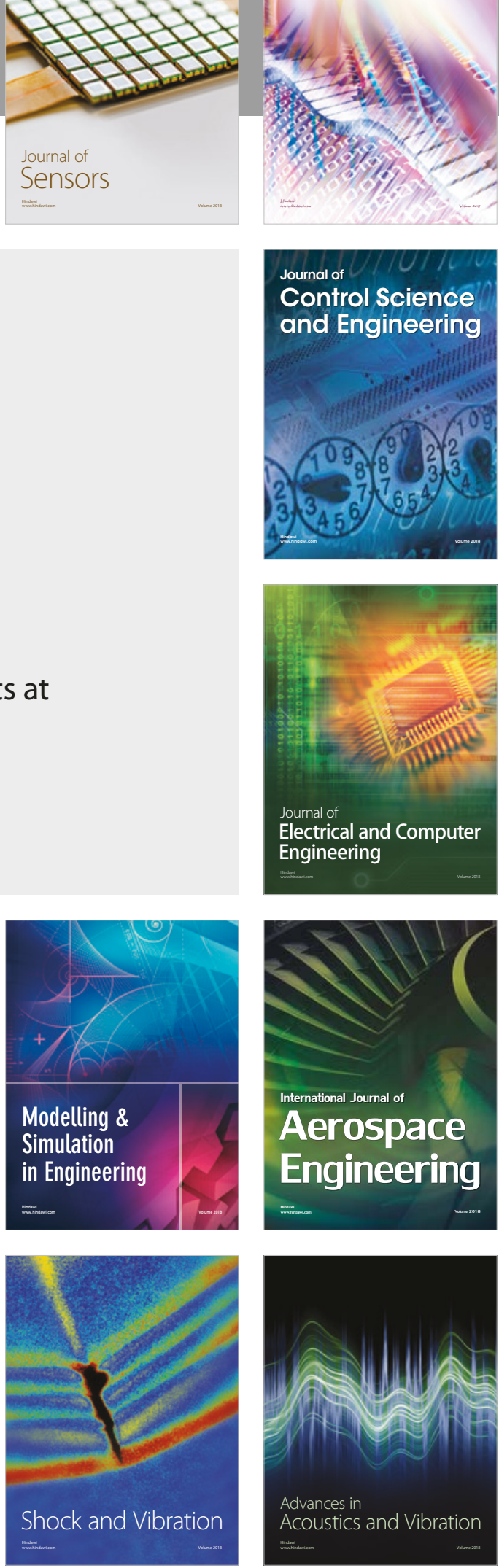